\title{
Emergency Remote Learning in Nursing Education During the COVID-19 Pandemic
}

\author{
Eunjoo JEON a , Laura-Maria PELTONEN ${ }^{\mathrm{b}}$, Lorraine BLOCK ${ }^{\mathrm{c}}$, Charlene \\ RONQUILLO $^{\mathrm{d}}$, Jude L. TAYABEN ${ }^{\mathrm{e}}$, Raji NIBBER ${ }^{\mathrm{f}}$, Lisiane PRUINELLI ${ }^{\mathrm{g}}$, Erika \\ Lozada PEREZMITRE ${ }^{\text {h }}$, Janine SOMMER ${ }^{\mathrm{i}}$, Maxim TOPAZ ${ }^{\mathrm{j}}$, Gabrielle Jacklin \\ ELER $^{k}$, Henrique Yoshikazu SHISHIDO ${ }^{1}$, Shanti WARDANINGSIH ${ }^{\mathrm{m}}$, Sutantri \\ SUTANTRI $^{\mathrm{m}}$, Samira ALI ${ }^{\mathrm{n}}$, Dari ALHUWAIL ${ }^{\circ}$, Alaa Abd-ALRAZAQ ${ }^{\mathrm{p}}$, Laila Akhu- \\ ZAHEYA $^{\mathrm{q}}$, Ying-Li LEE ${ }^{\mathrm{r}}$, Shao-Hui SHU ${ }^{\mathrm{s}}$, and Jisan LEE ${ }^{\mathrm{t}, 1}$ \\ a Technology Research, SamsungSDS, Republic of Korea \\ ${ }^{\mathrm{b}}$ Department of Nursing Science, University of Turku, Finland \\ ${ }^{\mathrm{c}}$ School of Nursing, University of British Columbia, Canada \\ ${ }^{\mathrm{d}}$ School of Nursing, University of British Columbia Okanagan, Canada \\ ${ }^{\mathrm{e}}$ College of Nursing, Benguet State University, Philippines \\ ${ }^{\mathrm{f}}$ Cancer Care, Fraser Health Authority, Canada \\ ${ }^{\mathrm{g}}$ School of Nursing, University of Minnesota, USA \\ ${ }^{\mathrm{h}}$ Nursing Faculty, Benemérita Universidad Autónoma de Puebla, Mexico \\ iHealth Informatics Department, Hospital Italiano de Buenos Aires, Argentina \\ ${ }^{\mathrm{j} S c h o o l}$ of Nursing, Columbia University Data Science Institution, USA \\ ${ }^{\mathrm{k}}$ Collegiate of Nursing, Federal Institute of Paraná, Brazil \\ ${ }^{1}$ Department of Computing, Federal University of Technology - Paraná, Brazil \\ ${ }^{\mathrm{m}}$ School of Nursing, University Muhammadiyah of Yogyakarta, Indonesia \\ ${ }^{\mathrm{n}}$ Department of Nursing, Grand Canyon University, USA \\ ${ }^{\circ}$ Information Science Department, Kuwait University, Kuwait \\ ${ }^{\mathrm{p}}$ College of Science and Engineering, Hamad Bin Khalifa University, Qatar \\ ${ }^{q}$ School of Nursing, Jordan University of Science and Technology, Jordan \\ ${ }^{\mathrm{r}}$ College of Health Science, Chang Jung Christian University, Taiwan \\ ${ }^{\mathrm{s}}$ College of Nursing, Tzu University of Science and Technology, Taiwan \\ ${ }^{\mathrm{t}}$ Department of Nursing, Hoseo University, Republic of Korea
}

\begin{abstract}
Due to the corona (COVID-19) pandemic, several countries are currently conducting non-face-to-face education. Therefore, teachers of nursing colleges have been carrying out emergency remote education. This study developed a questionnaire to understand the status of Emergency Remote Learning (ERL) in nursing education internationally, translated it into 7 languages, and distributed it to 18 countries. A total of 328 nursing educators responded, and the most often used online methods were Social networking technology such as Facebook, Google+ and Video sharing platform such as YouTube. The ERL applied to nursing education was positively evaluated as 3.59 out of 5 . The results of the study show that during the two semesters nursing college professors have well adapted to this unprecedent crisis of teaching. The world after COVID-19 has become a completely different place, and nursing education should be prepared for 'untact' education.
\end{abstract}

\footnotetext{
${ }^{1}$ Corresponding Author, Jisan Lee, Department of Nursing, Hoseo University, Asan, Republic of Korea; E-mail: saan2mari@gmail.com
} 
Keywords. COVID-19, Nursing education, Distance educational technology, Emergency remote learning

\section{Introduction}

The coronavirus (COVID-19) outbreak which began in Wuhan, in the Hubei province of China, at the end of December 2019, seems to impact our society at all levels in terms of fast global spreading [1]. COVID-19 was designated a pandemic by WHO in March 2020 and has been a source of negative influence not only for our daily lives but for the field of nursing and nursing education [2].

School closures took place across mainland China at the end of January 2020, for four weeks in Hong Kong in February 2020, followed by massive school closures in many countries to prevent the spread of COVID-19 [3]. In these circumstances, nursing education had to embrace a new paradigm shift. Offline education is no longer available, all nursing curriculum including practical classes have to be conducted online. In this way, an education method that temporarily switches to online in a crisis such as COVID19 is formally named Emergency Remote Learning (ERL) [4].

To date, research into ERL or online nursing education methods caused by COVID19 has been conducted only nationally. Therefore, this study attempts to investigate the current status and provide improvement comments of emergency remote learning (ERL) from an international perspective.

\section{Methods}

\subsection{Questionnaire design}

The questionnaire was developed through repeated discussion by 11 IMIA-NI SEP members referring to literature on COVID-19 online education. The final questionnaire was translated into 7 languages (Arabic, English, Korean, Bahasa Indonesia, Portuguese, Español and Traditional Chinese). Each translation was done by bilingual-speaking nurses with a background in nursing informatics. Translations have been verified by at least two other bilingual-speaking NI professionals and revised until a final version was produced [5].

The questionnaires consist of 21 questions and have both structured and open-ended response options. There are 7 demographic questions for teacher: age, country and city, current position, education-level, educational background, teaching year, and subject type [6-10]. The 11 questions are on the ERL in nursing education, all used Likert 5point scale from 'not much' to 'very much'. Eleven questions are on ERL teaching methods, overall satisfaction, contents, delivery, teacher-student interaction, burden, technology self-efficacy, support, and willingness to use in the future [6, 8, 11-14]. Lastly, there are three open-ended questions for collecting free comments on ERL. This paper focuses on the quantitative responses to 11 questions about ERL.

\subsection{Collecting data}

Our study was approved by the institutional review boards at the Hoseo University (IRB No.1041231-200825-HR-114-01). Any professor (or instructor) with experience in 
nursing education after COVID-19 pandemic (since January 2020) was eligible to participate. We used snowball sampling to reach as many international respondents as possible. The surveys were distributed and the responses were collected using Google Forms. The datasets were collected from November 2020 to January 2021.

\subsection{Analysis}

Analysis process is conducted by Python (3.6.9), numpy (1.19.4), pandas (1.1.5), and skilearn (0.22.2.post1) library. Descriptive statistical analysis of general characteristics and ERL is performed.

\section{Results}

Total of 328 respondents who answered the questions focused on ERL in nursing. Responders were from 18 different countries in Brazil, Indonesia, South Korea, Jordan, Philippines, Taiwan, Argentina, Canada, Finland, USA, Mexico, Italy, India, Portugal, Saudi Arabia, Scotland, Switzerland, and Turkey. The professional positions of the respondents were Professor (7.3\%), Associate professor (13.1\%), Assistant professor $(25.9 \%)$, Instructor $(52.1 \%)$ and Others $(1.5 \%)$. The ages of respondents were in $20 \mathrm{~s}$ (4.6\%), 30s (36.3\%), 40s (35.4\%), 50s (14.3\%), 60 years old $(8.8 \%)$, and no respondents $(0.6 \%)$. More than half of the respondents had a $\mathrm{PhD}(55.2 \%)$ and $38.4 \%$ of them had a Master's degree.

Online methods used in the Covid-19 situation are 1) Social networking technology such as Facebook, Google+, WhatsApp, Twitter (46.0\%), 2) Video sharing platform such as YouTube, Flipgrid (43.9\%), 3) Learning Management System such as Google classroom, Moodle, Blackboard, Elevate, Flinga (39.9\%), 4) Institution's online platform (29.9\%), 5) Video conference system such as Zoom, Microsoft Teams, Hangout Meet, Skype etc. (14.6\%), 6) Game-based learning platform such as Kahoot (14.0\%), 7) Blog or website $(11.0 \%), 8)$ Massive Open Online Courses such as Coursera, Canvas Network (8.5\%), and 9) Virtual learning system such as SecondLife, vSim (4.9\%). The response results for ERL status are shown in Table 1.

Table 1. Likert 5-point scale response result for ERL status $(\mathrm{n}=328)$

\begin{tabular}{|c|c|c|}
\hline Concepts & Questions & $\begin{array}{c}\text { Mean } \\
\text { (std) }\end{array}$ \\
\hline $\begin{array}{l}\text { Overall } \\
\text { satisfaction }\end{array}$ & $\begin{array}{l}\text { Overall, Emergency Remote Teaching (chosen in the previous question) } \\
\text { worked well in my teaching }\end{array}$ & $\begin{array}{l}3.59 \\
(0.83)\end{array}$ \\
\hline Contonto & $\begin{array}{l}\text { Emergency Remote Teaching provided in-depth learning opportunities } \\
\text { for students when compared to my traditional teaching }\end{array}$ & $\begin{array}{l}2.96 \\
(1.06)\end{array}$ \\
\hline Contents & $\begin{array}{l}\text { Emergency Remote Teaching provided a wide range of learning } \\
\text { opportunities for students when compared to my traditional teaching. }\end{array}$ & $\begin{array}{l}3.20 \\
(1.05)\end{array}$ \\
\hline Delivery & $\begin{array}{l}\text { Emergency Remote Teaching delivered exactly what I originally } \\
\text { planned regardless of COVID- } 19\end{array}$ & $\begin{array}{l}2.83 \\
(1.17)\end{array}$ \\
\hline Teacher-student & The teacher-student interaction worked equally well in Emergency & 2.67 \\
\hline interaction & Remote Teaching compared to traditional methods & $(1.18)$ \\
\hline Burden & $\begin{array}{l}\text { Moving into Emergency Remote Teaching from traditional teaching has } \\
\text { been a burden for me }\end{array}$ & $\begin{array}{l}3.27 \\
(1.25)\end{array}$ \\
\hline $\begin{array}{l}\text { Technology self- } \\
\text { efficacy }\end{array}$ & $\begin{array}{l}\text { I have become much more confident in dealing with technology of } \\
\text { online teaching since the Emergency Remote Teaching started }\end{array}$ & $\begin{array}{l}3.76 \\
(1.05)\end{array}$ \\
\hline Support & $\begin{array}{l}\text { It has been easy to find help on using digital/online education material } \\
\text { for Emergency Remote Teaching }\end{array}$ & $\begin{array}{l}3.61 \\
(1.07)\end{array}$ \\
\hline
\end{tabular}


My institution/school has fully supported the transfer of my teaching 3.88 into Emergency Remote Teaching

\section{Discussion}

Overall satisfaction with ERL nursing education due to coronavirus was 3.59 on average, with a high positive evaluation. In-depth learning, educational delivery, and teacherstudent interaction, which were pointed out as disadvantages of online education, had a negative rating of less 3 . Burden turned out to be many in changing from traditional teaching methods to ERL or online education.

Nevertheless, it has been found that teachers' technology self-efficacy has been increased by applying ERL, and each university has been giving appropriate support for teachers. In addition, there were many opinions that the ERL method currently being used are likely to be used in the future.

\section{Conclusion}

In this paper we analyzed the status of ERL in nursing education based on the 328 responses from nursing professors and instructors of the 18 countries. Online or distance learning applied to the pandemic was seen confusing at first, but the results of our study show that after the two semesters the nursing college teachers have adapted well. Life after COVID-19 has become a completely different world, and nursing education should now be prepared for 'untact' education. In the future, additional qualitative analysis will be conducted by natural language processing methods for open-ended questions.

\section{Acknowledgement}

This research was supported by the Basic Science Research Program through the National Research Foundation of Korea funded by the Ministry of Education (NRF2018R1C1B5030802).

We thank the IMIA-NI group leadership NI experts for their support and feedback on the survey and all who helped to distribute the survey.

\section{References}

[1] Wang C, Horby PW, Hayden FG, Gao GF. A novel coronavirus outbreak of global health concern. The Lancet. 2020; 395(10223): 470-3.

[2] Atique S, Bautista JR, Block LJ, Lee JJ, Lozada-Perezmitre E, Nibber R, O'Connor S, Peltonen LM, Ronquillo C, Tayaben J, Friederike JS, Topaz M. A nursing informatics response to COVID-19: perspectives from five regions of the world. J Adv Nurs. 2020;76:2462-8.

[3] Viner RM, Russell SJ, Croker H, Packer J, Ward J, Stansfield C, Mytton O, Bonell C, Booy R. School closure and management practices during coronavirus outbreaks including COVID-19: a rapid systematic review. The Lancet Child \& Adolescent Health. 2020;4(5):397-404. 
[4] Hodges C, Moore S, Lockee B, Trust T, Bond A. The difference between emergency remote teaching and online learning. Educause Review. 2020;27:1-12.

[5] Topaz M, Ronquillo C, Peltonen LM, Pruinelli L, Sarmiento RF, Badger MK, Ali S, Lewis A, Georgsson M, Jeon E, Tayaben JL, Kuo CH, Islam T, Sommer J, Jung H, Eler GJ, Alhuw AIL D. Advancing nursing informatics in the next decade: recommendations from an international survey. In: W. Sermeus et al, editors. Proceedings of the 13th International Congress in nursing informatics: EHealth for All: Every Level Collaboration-From Project to Realization; 2016 June 25-29; Geneva, Switzerland: 2016 IMIA and IOS Press; 225. p. 123-7.

[6] Kent AM, Giles RM. Preservice Teachers' Technology Self-Efficacy. SRATE Journal. 2017; 26(1): 920.

[7] Peltonen LM, Pruinelli L, Ronquillo C, Nibber R, Peresmitre EL, Block L, Deforest H, Lewis A, Alhuwail D, Ali S, Badger MK, Eler GJ, Georgsson M, Islam T, Jeon E, Jung H, Kuo CH, Sarmiento RFR, Sommer JA, Tayaben J, Topaz M. The current state of Nursing Informatics-An international crosssectional survey. Finnish Journal of eHealth and eWelfare. 2019;11(3):220-31.

[8] Roach V, Lemasters L. Satisfaction with online learning: A comparative descriptive study. Journal of Interactive Online Learning. 2006; 5(3): 317-32.

[9] Jeon E, Kim J, Park H, Lee JH, Kim J, Jin M, On J. Current status of nursing informatics education in Korea. Healthcare informatics research. 2016; 22(2): 142-50.

[10] Mitchell MM, Delgado C. Online learning: Advantages and challenges in implementing an effective practicum experience. Open Journal of Nursing. 2014; 4(6): 379-84.

[11] Shelton BE, Hung JL, Lowenthal PR. Predicting student success by modeling student interaction in asynchronous online courses. Distance Education. 2017; 38(1): 59-69.

[12] Hung ML. Teacher readiness for online learning: Scale development and teacher perceptions. Computers \& Education, 2016; 94: 120-33.

[13] Vicki Villa. The burden of switching to online education falls mostly on teachers. The Dallas Morning News, 19 April 2020,

[14] Hodges C, Moore S, Lockee B, Trust T, Bond A. The difference between emergency remote teaching and online learning. Educause Review. 2020; 27:1-15. 